\title{
PENEGAKAN HUKUM SYARAT MUTLAK MEWUJUDKAN NEGARA HUKUM DAN TUJUAN NEGARA (PENELITIAN PENEGAKAN HUKUM LALULINTAS JALAN DI KAWASAN SENEN)
}

\author{
Oleh Muchtar B. Pakpahan ${ }^{1}$ \\ Email: muchtarpakpahan_assocites@yahoo.com \\ Universitas Kristen Indonesia
}

\begin{abstract}
A country of law requires the existence of law enforcement, in this case the goal is just for well being and the protection of citizens rights, protecting all the regions, as well giving a guarantee to each of these members of the community to impose their daily activities, it has a legal state laws, there is a body of justice that free and impartial, having basic laws, providing education, maintainning discipline on society, provide the security to any members of the community for activities every single day include in the convenience on the road, such as: pleasantness of pedestrians orderlines the user of motorcyles, distraction from vendors, the protection an area of the sidewalk from vendors, the side of the road users as parking spaces, The discipline user on the road, the obediance of pedestrian for using overpass, if all these things happened then must be law enforcement, especially operationalising the traffic of law in transportation roadway by the sipport of the technology and the officers who disciplines.
\end{abstract}

Keywords: penegakan hukum syarat untuk negara hukum

\section{Pendahuluan}

Membahas judul ini dengan pendekatan konstitusional harus dimulai dari Pembukaan UUD1945 alinea 4 yang menggariskan tujuan negara. Selengkapnya saya kutip². “...membentuk suatu pemerintahan Negara Indonesia yang melindungi segenap bangsa Indonesia dan seluruh tumpah darah Indonesia dan untuk memajukan kesejahteraan umum, mencerdaskan kehidupan bangsa, dan ikut melaksanakan ketertiban dunia...." Kutipan inilah tujuan negara Indonesia merdeka, yang bila dikaji secara teoritis itulah negara dengan sistem negara bertanggungjawab mensejahterakan rakyatnya atau welfarestate. Berarti tujuan mendirikan negara welfarestate adalah cita-cita perjuangan Soekarno memerdekakan Indonesia ${ }^{3}$.

Empat butir welfarestate itu adalah suatu tujuan yang utuh sebagai satu kesatuan. Tetapi satu dari antaranya yakni butir 1 menjadi pokok kajian dalam tulisan ini "melindungi segenap bangsa Indonesia dan seluruh tumpah darah Indonesia". Kalimat ini harus diartikan sebagai jaminan adanya penegakan

\footnotetext{
${ }^{1}$ Guru Besar pada Universitas Kristen Indonesia Jakarta

${ }^{2}$ Fokus Media, UUD’45 dan Amandemennya, hal 1-2.

${ }^{3}$ Soekarno dalam pleidoi yang berjudul Indonsia Menggugat menegaskan, "kalau saya berhasil memerdekakan Indonesia, saya akan membangun negara welfarestate atas dasar demokrasi so- sial seperti di negara Tuan", maksudnya Belanda.
}

hukum bagi setiap individu maupun komunitas serta melindungi semua wilayah. Atau dengan bahasa lain, melindungi segenap bangsa berarti memberi jaminan kepada setiap warganegara dan setiap kelompok masyarakat akan mendapatkan hak dan kewajibannya. Melindungi seluruh tumpah darah Indonesia ber- arti menjaga kedaulatan wilayah Indonesia dan mempertahankan seluruh wilayah Indonesia. Tentu melakukan dua kewajiban itu adalah dengan hukum, dengan undang-undang dan dengan peraturan. Untuk melindungi manusia dan wilayah tadi, dibutuhkan kekuasaan baik kekuasaan eksekuitif, legislatif dan judikatif. Berarti hukum menjadi dasar mencapai tujuan negara, dan penegakan hukum adalah mutlak perlu dalam rangka mencapai tujuan negara.

Selanjutnya ada dua istilah yang akan mendapat pembahasan yakni negara hukum dan penegakan hukum. Kemudian berkaitan dengan kajian ini, alinea 4 ini memiliki multimakna dan multifungsi, yakni:

1. Menegaskan manfaat merdeka dan membentuk pemerintahan sendiri lepas dari pemerintahan kolonial Belanda.

2. Menegaskan tujuan kemerdekaan sebagaimana diungkapkan di alinea 4 yang saya artikan sebagai welfarestate.

3. Menjadi alat ukur untuk menguji (mengevaluasi) apakah suatu rezim pemerintahan berhasil atau gagal. 
Memang sulit mendefinisikan apa yang dimaksud hukum. Tetapi menurut saya ada lima ciri sekaligus syarat yang dimaksud hukum ${ }^{4}$;

1. Seperangkat peraturan, ketentuan, atau kaidah.

2. Berbentuk tertulis atau lisan.

3. Diterima sebagai pencipta keadilan dan kepastian.

4. Ada sanksi atau hukuman bagi pelanggar.

5. Ada instansi yang ditugaskan menerapkan sanksi memberikan hukuman.

Apa yang digambarkan sebagai 5 ciri hukum, keberlakuannya dan penerapannya dalam pembahasan ini adalah hukum dalam wilayah NKRI (Negara Kesatuan Republik Indonesia) yang berdasarkan Pancasila dan konstitusi UUD 1945. Selanjutnya dalam Pasal 1(3) UUD ditegaskan bahwa Indonesia adalah Negara Hukum ${ }^{5}$. Yang dicirikan dengan 5 ciri sebagai hukum, berlaku di NKRI.

Negara hukum "rule of law" menjadi hanya sebuah pernyataan bila penegakan hukum "Law Enforcement" lemah. Hukump un demikian menjadi tidak mempunyai arti apabila apa yang dituju hukum itu tidak dijalankan dengan tindakan nyata penegakan hukum. Itulah yang diteliti pada studi ini khususnya penegakan hukum lalulintas di Jakarta, dan lokasi Pasar Senen menjadi lokasi penelitiannya.

\section{Permasalahan}

Apakah penegakan hukum menjadi syarat mutlak mewujudkan negara hukum dan tujuan Negara?

\section{Tujuan}

Untuk mengetahui bahwa penegakan hukum menjadi syarat mewujudkan negara hukum dan tujuan negara.

\section{Penjelasan Penelitian}

Mahasiswa kelas mata kuliah Dasar-dasar Ilmu Hukum Fakultas Hukum UKI yang sedang saya ajar pada semester I tahun ajaran 2017-2018, saya tugasi melakukan penelitian. Mereka yang melaksanakan penelitian adalah (1) Amri Simbolon; (2) Amon Fiago Sianipar; (3) Anggelina Syntia Pamela Panjaitan; (4) Angel Nadia Naro; (5) Aurelia Rahel;

(6) Deasy Anderesta Marbun; (7) Dimas Suprayogi;

(8) Fisensia Wau; (9) Fitriyani Wospakrik; (10)

Giovani Kurniawan; (11) Gress Elly; (12) Gresia; (13) Ivan Ria Rita Harefa; (14) Melcianus Galla; (15) Javier Alexander; (16) Leonardo; (17) Manurung; (18) Michelle Olivia; (19) Naomi Michelle Olivia; (20) Polman Alkdo Fransisco; (21) Rafael Manaek

\footnotetext{
4 Syarat ini sering saya ajarkan di kelas FH UKI dan juga

setiap saya memberi kajian tentang hukum. Dengan demikian mempermudah menjelaskan apa yang dimaksud dengan hukum.

${ }^{5}$ Fokus Media, UUD’45 dan Amandemennya.
}

Parulian; (22) Reinhart Hamonangan Gurning; (23) Shintia Eliana Sinaga; (24) Simon Petrus Simbolon; (25) Vandu Feredrik Ompi; (26) Yessi Melati; (27) Yulius; dan (28) Widia Vlorensia.

Penelitian dilakukan dengan memilih lokasi Pasar Senen, dari jalan Suprapto mulai dari rel kereta Api hingga ke jalan Gunung Sahari berlanjut ke Kramat Raya, ada pemotongan menuju jalan Bungur Raya. Alasan memilih lokas ini, lokasi ini relatif di tengah kota, dapat dibuat menjadi salah satu percontohan tingginya intensitas pelanggaran hukum lalulintas, dan memberi solusi penegakan hukum di Pasar Senen dapat dibuat menjadi pola ke seluruh DKI Jakarta dan mungkin seluruh Indonesia. Penelitian dilakukan dengan dua tahap. Tahap pertama adalah survei dari Minggu tanggal 1 s.d. Minggu 8 Oktober 2017. Tahap kedua mendata jumlah pelanggar setiap kategori pelanggaran hukum, dari Minggu 15 Oktober s.d. Minggu 22 Oktober 2017.

Pada tahap pertama setiap mahasiswa ditugaskan selama 2 (dua) jam mengamati pelanggaran hukum lalulintas apa yang dilakukan. Waktunya terserah dari batasan jam 06.00 s.d. 18.00 sore dan tidak diperbolehkan mahasiswa lebih dari satu orang melakukan pengamatan pada jam yang sama. Alasan memilih jam 06.00 s.d.18.00 adalah untuk mendapatkan pelanggaran hukum lalulintas padajam matahari masih bersinar. Berarti dari pengamatan 56 jam dari tanggal 1 s.d. 8 Oktober 2017 didapatlah jenis/kategori pelanggaran hukum lalulintas.

Pada tahap kedua, setiap mahasiswa ditugaskan selama 2 (dua) jam melakukan pencatatan jumlah pelanggaran hukum lalulintas dari setiap kategori yang telah ditetapkan. Waktunya terserah mereka dengan batasan jam 06.00 s.d. 18.00 selama matahari bersinar. Penelitian tahap kedua ini menghasilkan kuantitas intensitas pelanggaran hukum lalulintas ditambah dengan ada catatan khusus.

\section{Negara Hukum}

Sejarah negara hukum, sama tuanya dengan sejarah demokrasi. Namun, hampir seluruh studi tentang negara hukum dan demokrasi berhenti pada hulu trio philossopher, yakni Socrates, Plato, dan Aristoteles. Ketiganya merupakan rujukan otoritatif sejarah yang dipuja dan selalu hidup meskipun zaman dan sejarah berganti ${ }^{6}$. Berarti tentang negara hukum dan demokrasi adalah dua thema yang sudah berumur ribuan tahun, namun tetap mempunyai masalah di setiap zamannya. Penegasan Indonesia adalah Negara

\footnotetext{
${ }^{6}$ Fajlurrahman Jurdi, Teori Negara Hukum, Setara Press, Malang, 2016, halaman 2-3.
} 
Hukum, menunjukkan dengan tegas sikap para pendiri bangsa yang menginginkan Indonesia sebagai negara hukum, bukan sebagai negara kekuasaan ${ }^{7}$.

Berikut ini beberapa pendapat tentang negara hukum. Ciri-ciri negara hukum (rechstaat) menurut Friedrich Julius Stahl ${ }^{8}$ :

1. Ada perlindungan terhadap Hak-hak Azasi Manusia (HAM)

2. Ada pembagian kekuasaan trias politica untuk menjamin HAM

3. Pemerintahan berdasarkan peraturan (hukum, undang-undang dasar pen)

4. Peradilan administrasi dalam perselisihan. Ciri-ciri Negara Hukum menurut International

Commission of Jurist Bangkok 1965 adalah ${ }^{9}$ :

1. Adanya perlindungan konstitusional terha- dap HAM dan tersedia prosedur untuk memperolehnya.

2. Ada Badan Kehakiman yang bebas dan tidak memihak

3. Ada jaminan kebebasan menyatakan pendapat.

4. Terselenggara pemilihan umum yang bebas secara reguler.

5. Adanya jaminan kebebasan berorganisasi

6. Terselenggara pendidikan civics (kewarganegaraan).

Frans Magnis Suseno mengemukakan ciri negara hukum sebagai ciri demokrasi adalah ${ }^{10}$ :

1. Fungsi kenegaraan dijalankan sesuai UUD.

2. UUD menjamin HAM

3. Badan Negara menjalankan kekuasaan taat pada hukum yang berlaku.

4. Terhadap tindakan negara masyarakat dapat mengadu ke pengadilan dan putusannya harus dilaksanakan badan negara.

5. Badan kehakiman bebas dan tidak memihak.

Dari ciri-ciri yang dikemukakan di atas, dapat saya simpulkan bahwa negara hukum itu adalah negara yang mempunyai UUD serta taat menjalankannya, UUD memberikan jaminan perlindungan HAM, ada badan peradilan yang menjaminnya, dan negara serta pemerintahan negara tunduk pada hukum UUD dan Undang-undangdantaatmelaksanakanhukum.Intinya ada hukum (baca UUD dan UU), pemerintah tunduk

\footnotetext{
${ }^{7}$ Bambang Waluyo, Penegakan Hukum di Indonesia, Sinar Grafika, cetakan kedua 2017, Jakarta, halaman 137.

${ }^{8} \mathrm{Ibid}$, halaman 21.

${ }^{9}$ Muchtar Pakpahan, DPR Semasa Orde Baru, Sinar Harapan, Jakarta, 1993

${ }^{10}$ Fajrulrahman Jurdi, halaman 21.
}

dan menjalankan hukum, serta pemerintah dapat dimajukan ke pengadilan mempertanggungjawabkan tindakannya. Pendapat ini diperkuat kalimat kutipan berikut ${ }^{11}$ : "mengandung konsekwensi logis, bahwa negara Indonesia berpegang pada supremasi hukum, artinya hukum digunakan sebagai dasar dan landasan pijak setiap perbuatan masyarakat atau warga negara termasuk aparatur penegak hukum".

Pernyataan negara hukum tidak berarti apa-apa atau sama sekali tidak mempunyai arti bila hukum itu tidak ditegakkan. Bila pelanggaran terhadap hukum itu tidak dijatuhkan sanksi sesuai hukum positif yang telah mengaturnya maka negara hukum menjadi tanpa makna. Dan juga negara hukum itu tidak berarti sama sekali bila pemerintah mengabaikan hukum. Karena itu negara hukum akan memiliki arti bila ada Penegakan Hukum oleh pemilik kewenangan menjalankan penegakan hukum baik Eksekutif dan maupun Judikatif. Yang Eksekutif dibawahpimpinan Presiden yakni Kepolisian, Kejaksaan, dan Hukum dan HAM serta sesungguhnya semua instansi yang diberi kewenangan khusus KPK untuk korupsi, Kemenaker c.q. Dirjen Pengawasan untuk Pidana Ketenagakerjaan, Dirjen Pajak untuk pajak dan instansi lainnya.

Sekarang berlanjut dengan membahas Penegakan Hukum. Yang saya maksudkan dengan Penegakan hukum atau padanannya dalam bahasa Inggris Lawenforcement, terlebih dahulu saya kutip dalam bahasa Inggris ${ }^{12}$. Enforcement $n$, act or process of enforcing. Enforce (ing) v.t. to ensure the observance of law or rule. To compel by physical or moral force to: enforced payment by threats of legal action. Jadi penegakan hukum itu adalah sebuah tindakan atau proses yang memaksa orang mematuhi hukum dengan paksaan moral atau fisik. Atau lebih tajam bila dinyatakan bahwa penegakan hukum adalah tindakan menerapkan hukum terutama dalam pemberian sanksi moral atau sanski fisik. Tujuan dari penegakkan hukum itu adalah menegakkan hukum dan memberi kepastian hukum yang ahirnya memberi rasa keadilan dan rasa nyaman di masyarakat.

Saya aktif sebagai praktisi hukum sejak tahun 1978, aktif sebagai akademisi dosen sejak tahun 1981, dan aktif mengadvokasi komunitas buruh sejak 1978 dan sebagai unionis (unionis adalah orang yang bekerja di Serikat Buruh atau union) di Serikat

\footnotetext{
${ }^{11}$ Sadjijono, Prof., Dr., SH, M.Hum, Hukum Antara Sollen dan Sein (Dalam perspektif Praktek Hukum di Indonesia), halaman 37.

${ }^{12}$ Dictionary, Macmillan Publishing Co,,Inc, Newyork and Collier Macmillian Publisher, 1977, hal 338.
} 
Buruh Sejahtera Indonesia sejak tahun 1992. Dalam tiga pengalaman tersebut, dapatlah saya nyatakan bahwa apa yang saya tuliskan ini merupakan proses perjalanan hidup dan perenungan panjang tentang penegakan hukum di Indonesia ditambah dengan melakukan penelitian pengamatan tentang penegakan hukum sejak Juni 2013 hingga Juli 2015 dan menugaskan mahasiswa melakukan penelitian di sekitar Pasar Senen tahun 2017.

\section{Masalah Pokok yang Dikaji}

Ada dua masalah pokok yang dikaji dalam tulisan ini yakni Negara Hukum dan Penegakan Hukum, yang dirangkai menjadi Penegakan Hukum dalam tindakan nyata pemberian Sanksi Hukum kepada pelanggar hukum, sesuai perintah hukum sebagai Negara Hukum.

\section{Negara Hukum}

Indonesia adalah Negara Hukum. Dari pendekatan sejarah sistem hukum negara hukum "rule of law" dan "rechstaat", Indonesia adalah yang "rechstaat". Yang dimaksud dengan negara hukum adalah setiap kegiatan bernegara, berpemerintahan dan bermasyarakat dilaksanakan berdasarkan hukum tertulis. Pengertian ini secara teoritis disebut juga dengan pendekatan legalistik ${ }^{13}$. Pembahasan ini sejalan dengan pendapat Philipus M. Hadjon ${ }^{14}$. Dengan demikian ide dasar negara hukum Indonesia tidaklah lepas dari ide dasar tentang "rechstaat". Syarat-syarat dasar "rechstaat":

1. Asas legalitas, setiap tindak pemerintrahan harus didasarkan atas dasar peraturan perundangundangan (wettelijke grondslag). Dengan landasan ini, undang-undang dalam arti formal dan UUD sendiri merupakan tumpuan dasar tindakan pmerintahan. Dalam hubungan ini pembentukan undang-undang merupakan bagian penting negara hukum.

2. Pembagian kekuasaan, syarat ini mengandung makna bahwa kekuasaan negara tidak boleh hanya bertumpu pada satu tangan.

3. Hak-hak dasar (grondrechten), hak-hak dasar merupakan sasaran perlindungan hukum bagi

\footnotetext{
${ }^{13}$ Muchtar Pakpahan, Potret Negara Indonesia, cetakan III, PT BIS, 2011, hal 50

${ }^{14}$ Prof. Dr. Philipus M. Hadjon,SH, Ide Negara Hukum Dalam Sistem Ketatanegaraan Indonesia, dalam buku Kedaulatan Rakyat, Hak Azasi Manusia dan Negara Hukum, Sebuah Kumpulan Esai, Editor Bagir Manan, Penerbit Gaya Media Pratama, 1996, hal 7879.
}

frakyat dan sekaligus membatasi kekuasaan pembentukan undang-undang.

4. Pengawasan pengadilan, bagi rakyat tersedia saluran melalui pengadilan yang bebas untuk menguji keabsahan tindak pemerintahan (rechtmatigheids toetsing).

\section{Penegakan Hukum}

Ada dua kata yang disatukan menjadi satu pengertian yaitu penegakan (hukum) dan hukum (yang ditegakkan). Dari rangkaian dua kata tersebut, yang perlu terlebih dahulu dibahas pengertiannya dan sekaligus menjadi batasan pembahasan. Tentang Penegakan hukum Prof. Dr. Satjipto Rahardjo berpendapat " apabila berbicara tentang penegakan hukum, maka pada hakekatnya berbicara tentang penegakan ide-ide serta konsep-konsep yang nota bene adalah abstrak tersebut. Penegakan hukum merupakan suatu usaha untuk mewujudkan ide-ide tersebut menjadi kenyataan. Sedangkan perwujudan itu sebetulnya sudah memasuki bidang manajemen ${ }^{15}$.

Dapatkah terwujud suatu masyarakat yang tertib dan aman tanpa penegakan hukum pemberian sanksi? Atau dapatkah terwujud suatu masyarakat yang tertib dengan kesadaran hukum? Menurut saya harus terlebih dahulu ada penegakan hukum berupa pemberian sanksi baru tercipta masyarakat yang tertib dan aman, yang lambat laun menimbulkan kepatuhan atas hukum, dan lambatlaun menimbulkan kesadaran hukum.

Setiap orang tanpa terkecuali sama di mata hukum. Setiap orang yang melakukan pelanggaran hukum wajib diberikan sanksi sesuai aturan tertulis yang ada. Tidak dibenarkan ada pengecualian pemberian sanksi hukum atas tindakannya yang melanggar hukum. Inilah yang terjadi di negara kita, dan ini yang mendorong saya melakukan kajian penegakan hukum yang tidak jalan sesuai peraturan yang tertulis.

Sependapat dengan Jimly Asshiddiqie yang dimaksudkan dengan hukum dalam kajian ini adalah hukum formal. ${ }^{16}$ Dalam hal ini pengertian hukum juga mencakup makna yang luas dan sempit. Dalam arti luas, penegakan hukum itu mencakup pula nilai- nilai yang terkandung di dalamnya bunyi aturan formal maupun nilai-nilai keadilan yang hidup dalam

\footnotetext{
${ }^{15}$ Prof.Dr. Satjipto Rahardjo, SH, Penegakan Hukum, Suatu Tinjauan Sosiologis, Genta Publishing, cetakan II 2011, halaman 1

${ }^{16}$ Jimly Asshidiqqie, Penegakan Hukum, www.docudesk.com, Selasa 30 Juni 2015, hal. 1.
} 
masyarakat. Tetapi dalam arti sempit, penegakan hukum itu hanya menyangkut penegakan peraturan yang formal dan tertulis saja. Dengan demikian, hukum yang dimaksudkan adalah dalam pengertian sempit, yakni peraturan formal dan tertulis saja.

Juga sependapat Jimly Asshidiqie, penegakan hukum itu kurang lebih merupakan upaya yang dilakukan untuk menjadikan hukum dalam arti yang formil sempit, sebagai pedoman perilaku dalam setiap perbuatan hukum, baik oleh para subjek hukumyang bersangkutan maupun oleh aparatur penegak hukum yang resmi diberi tugas dan kewenangan oleh undangundang untuk menjamin berfungsinya norma-norma hukum yang berlaku dalam kehidupan bernegera dan ber-masyarakat Yang dipergunakan adalah dalam pengertian sempit penegakan hukum oleh aparatur negara.

\section{Pemberian sanksi hukum atau kesadaran hukum}

Menurut saya tujuan hukum adalah membangun kehidupan masyarakat yang tertib, semua orang menikmati adanya keadilan, terjamin hak-haknya, dan sehari-hari merasa hidup nyaman sesuai hukum (arti sempit) yang belaku. Kesimpulannya, tujuan hukum adalah terwujudnya masyarakat yang tertib dan aman seuai hukum yang berlaku.

Sejak Juni 2013 saya melakukan penelitian pengamatan terhadap tidak adanya pemberian sanksi kepada para pelanggar hukum. Yang saya teliti adalah dua sisi kehidupan sehari-hari;

1. Tentang kehidupan yang ada hubungannya dengan lalulintas langsung atau tidak langsung.

2. Tentang kehidupan yang ada hubungannya dengan perburuhan atau ketenagakerjaan.

Adapun penelitian yang saya lakukan berlangsung sejak Juni 2013. Alasannya, karena Juni 2013 itulah saya menyatakan Presiden Susilo Bambang Yudhoyono gagal menegakkan hukum dalam dua hal itu, lalu perlu mencari seorang presiden yang diharapkan mempunyai komitmen dan kemampuan menegakkan hukum. Dengan dasar itu jatuhlah pilihan menyatakan Joko Widodo sebagai calon presiden pada 13 Mei 2013, dan untuk memperjuangkan gagasan tersebut kami resmi mendirikan BARAJP (Barisan Relawan Jokowi for President) ${ }^{17}$.

Maksud menetapkan awal kajian ini Juni 2013, adalah ingin membuat titik tolak mengevaluasi:

\footnotetext{
${ }^{17}$ BARAJP dideklarasikan beberapa orang, di antaranya Sihol Manullang, saya, dan Roy Martin.
}

apakah ada perbedaan yang signifikan Juni 2013Oktober 2014 masa akhir kepresidenan Susilo Bambang Yudhoyono dengan Oktober 2014-Juli 2015 masa awal kepresidenan Joko Widodo. Atau adakah persamaan atau kelanjutan penegakan hukum Juni 2013-Oktober 2014 dengan Oktober 2014-Juli 2015. Hasil dari pengamatan itu akan dijelaskan di bab berikutnya.

\section{Pelanggaran Hukum Kehidupan Sehari-Hari}

Saya tinggal di Duren Sawit Jakarta Timur. Setiap hari kerja, saya melewati Jalan Dermaga, Jalan Bekasi Timur, Jalan Pemuda, Jalan Balap Sepeda, Jalan Perintis Kemerdekaan, Jalan Suprapto, Jalan Tanah Tinggi II, Jalan Kramat Raya/Salemba Raya,( Jalan Raden Saleh, Jalan Cikini Raya atau Jalan Proklamasi) Jalan Diponegoro, Jalan Salemba Raya, Jalan Pramuka, Jalan Pemuda, Jalan Bekasi Timur, Jalan Dermaga, kembali ke rumah dengan alamat Jalan Lingkar Dalam Kompleks PTB Blok B7 No 1, Duren Sawit. Dalam perjalanan sehari-hari ini, saya melakukan penelitian pengamatan yang menghasilkan sebuah penelitian tentang penegakan hukum yang tanpa arah berkaitan dengan lalulintas.

Pekerjaan saya sehari-hari adalah sebagai Pengajar di Fakultas Hukum Universitas Kristen Indonesia, Advokat, dan Ketua Umum DPP SBSI (Dewan Pengurus Pusat Serikat Buruh Sejahtera Indonesia). Dalam pekerjaan sebagai Advokat dan Ketua Umum DPP SBSI saya melakukan kajian terhadap kasuskasus yang saya tangani yang kebanyakan kasus perburuhan atau hubungan industrial. Kajian ini menghasilkan "penegakan hukum perburuhan atau hubungan industrial berlangsung tidak sesuai dengan Undang-undang ketenagakerjaan UU no 21 tahun 2000, UU no 13 tahun 2003 dan UU no 2 tahun 2004.

\section{Yang Berkaitan dengan Tertib Lalulintas}

Berikut ini akan dikemukakan berbagai pelanggaran lalulintas yang tidak mendapat sanksi hukum.

1. Pelanggaran Peraturan Lalulintas

Jalan Bekasi Timur, Jalan pemuda, Jalan Balap sepeda, Jalan Perintis Kemerdekaan, Jalan Kramat Raya/Salemba Raya, Jalan Pramuka adalah jalan yang semuanya sudah memiliki pemisah jalur kiri dan kanan. Tiap menit di jalanjalan yang disebut tadi ada pelanggaran lalulintas yang membahayakan pelanggar dan 
orang lain. Pelanggaran yang terbanyak melawan arus oleh sepeda motor. Bahkan jalan yang sudah satu arahpun dan padat kenderaan seperti jalan Proklamasi, Cikini Raya, Suprapto Senen dan Jalan Diponegoro masih banyak sepeda motor melawan arus. Yang terbanyak kedua melanggar rambu-rambu seperti menerobos lampu merah, menerobos verboden dan larangan memutar balik. Yang ketiga masuk jalur busway. Khusus mengenai jalur busway ini, sering terjadi mobil berplat TNI masuk jalur busway, lalu diikuti mobil lain. Kelihatannya polisi mempersilahkan TNI, tetapi yang pelanggar yang sipil di belakang TNI dihentikan polisi. Ini sering saya temukan di Jalan Suprapto dan Kramat Raya.

2. Pejalan kaki dan pedagang jalan seenaknya Pejalan kaki dan pedagang gerobak melintas di jalan raya seenaknya. Yang paling banyak melintas seenaknya di jalan raya yang jalur cepat, yang terbanyak kedua, melintas pada saat lampu hijau. Yang ketiga pedagang gerobak melintas melawan arus.

3. Usaha-usaha yang menggunakan bahu jalan. Di Jalan Balap Sepeda, Tanah Tinggi, Pramuka, Cikini Raya, dan Kramat Raya banyak usaha menggunakan bahu jalan sebagai tempat menjalankan usaha. Yang paling banyak bengkel mobil dan motor, kedua cat mobil, dan ketiga pedagang gerobak.

4. Trotoar menjadi tempat berdagang

Di semua jalan yang diteliti seperti disebut di atas, trotoarnya dipergunakan menjadi tempat berjualan. Akibatnya terpaksa pejalan kaki walaupun di jalan raya yang jalur cepat seperti Jalan Diponegoro, Cikini Raya, Raden Saleh, Balap Sepeda dan Suprapto Senen, terpaksa berjalan di bahu jalan raya yang sudah tentu membahayakan keselamatannya.

5. Buang sampah di sembarang tempat

Hampir setiap waktu ada saja orang yang buang sampah di sembarang tempat, termasuk di jalan raya. Pelakunya dari semua semua lapisan dan golongan: pejalan kaki, pedagang asongan dan gerobak, naik sepeda motor, dari kenderaan umum dan kenderaan pribadi dan bahkan beberapa naik mobil mewah. Anehnya sampah yang dibuang adalah semua jenis yakni sampah plastik, kertas pembungkus makanan dan rokok. Lokasi tempatnya bisa di lokasi lapisan bawah seperti Pasar Senen, dan bahkan di lokasi intelektual seperti Jalan Salemba Raya dan Diponegoro.

6. Parkir di bahu jalan

Parkir di bahu jalan raya amat sering terjadi dan mengganggu kelancaran serta mengakibatkan kemacetan. Ada yang terjadi pada jam-jam tertentu seperti masuk dan keluar sekolah di Jalan Pemuda depan UNJ, ada yang terus menerus karena tempat bekerja atau kantoran atau perusahaan atau pasar: Pasar Pramuka, Polresta Jakarta Pusat, Pasar Senen.

7. Ketidaknyamanan di kenderaan umum

Rasa tidak nyaman masih terus membayangi para penumpang kenderaan umum seperti bus, metromini dan angkot jenis mikrolet, karena acapkali terjadi tindakan kriminal, pencopetan, perampokan, penodongan dan pemerasan. Sepertinya orang ramai di dalam bus menjadi silent mayority yang tertekan atau yang tidak perduli. Isteri saya pernah naik bus Mayasari dari Pulogadung mau ke Tanah Tinggi, di perjalanan dirampok kalungnya, dan diancam siapa yang berani bantu. Dan siperampok turun di depan polsek Cempaka Putih. Selain hal yang telah dikemukakan di atas, adalagi ketidaknyamanan yang lain, yakni menurunkan penumpang sebelum tujuan dan memindahkannya ke kenderaan lain. Hanya orang yang terpaksa yang menumpang kenderaan umum.

8. Merokok di tempat yang tertulis dilarang merokok

Merokok adalah berbahaya bagi kesehatan paruparu dan jantung, karena itu di berbagai ruangan perkantoran dituliskan dilarang merokok. Tetapi kenyataan di hampir semua perkantoran yang saya amati terjadi pelanggaran terhadap larangan merokok. Bahkan di kantor yang semestinya menegakkan peraturan larangan merokok, justru orang yang berkantor di sana juga merokok, seperti kantor-kantor polisi, kantor walikota dan instansi gubernuran dan walikota. Yang paling tidak dapat diterima akal sehat, di gang-gang ruang tunggu Bandara, persis di tempat dilarang merokok, ada penumpang yang merokok walaupun sudah tersedia tempat merokok. Dan kenyataan lain dampak dari perokok, sering abu rokok bertebaran sehingga menimbulkan kesan kumuh setidaktidaknya tidak segar atau udaranya pengap.

\section{Pelanggaran Peraturan Perburuhan}

Berikut ini saya kemukakan berbagai pelanggaran 
hukum yang terkait dengan ketentuan perburuhan.

1. Lama putusan. Banyak putusan memakan waktu yang lama, bahkan hampir satu tahun tiba di tangan buruh yang berperkara. Padahal keseluruhan proses mulai dari mediasi hingga kasasi memakan waktu formal 110 hari kerja, UU no 2 tahun 2004 tentang Penyelesian Perselisihan Hubungan Industrial. 30 hari mediasi, 50 hari PHI dan 30 hari kasasi, total 110 hari kerja.

2. Putusan salah ketik. Ada beberapa putusan MA setelah diterima ternyata ada salah ketik yang menimbulkan sasaran putusan menjadi keliru. Memperbaikinya hampir sama prosedur dan waktunya dengan proses perkara biasa.

3. Kasusnya sama tetapi beda putusan. Ada kasus yang sama, beda buruhnya sengaja dipisah menghindri biaya perkara, tetapi putusannya berbeda. Yang satu ditolak dan yang lainnya dikabulkan.

4. Biaya perkara PHI. Buruh sangat sulit kalau dibebani biaya perkara.

5. Posisi Hakim Adhok. Salah satu harapan buruh terhadap reformasi adalah adanya peradilan perburuhan yang adil yang menjaga kepentingan buruh yang lemah. Itulah yang mendorong ada hakim adhok, yang kehadirannya secara secara adhok membela kepentingan buruh beracara, seperti posisi Arbiter dalam Pengadilan Niaga. Tetapi saat ini posisi Hakim Adhok sudah sama dengan hakim biasa.

6. Proses eksekusi yang lama. Prakteknya proses eksekusi perkara perdata pada umumnya diperlakukan sama dengan proses eksekusi PHI.

7. Pengawasan. Beberapa kali terjadi pertimbangan dan putusan hakim tidak sejalan dengan undangundang, antara lain kasasi terhadap perselisihan kepentingan, yang oleh UU No 2 tahun 2004 tidak diperbolehkan.

8. Penegakan hukum pidana perburuhan pasal 28 jo 43 UU No 21 tahun 2000, masalah saksi.

- Pasal tersebut sudah menggariskan adalah pelanggaran berat bila pengurus dan anggota serikat buruh diphk, dimutasi, didemosi dan diintimidasi. Namun penyidik kepolisian sering memanggil saksi ahli yang memberi keterangan bahwa phk, mutasi demosi adalah hak pengusaha tanpa kecuali pengurus atau anggota serikat buruh.

- Tentang kualifikasi saksi ahli. Sering terjadi yang diperiksa memberi keterangan ahli adalah PNS di disnaker atau kemmenaker. Menjadi permasalahan, apakah setiap PNS di kementerian ketenagakerjaan dapat menjadi saksi ahli? Atau siapa yang dimaksud sebagai saksi ahli? Praktek selama ini S1 ekonomi, administrasi, hukum, pangkat III/d dan IV/ a dan tidak faham perburuhan secara historis, filosofis dan sosiologis dan politis dimintai keterangan sebagai saksi ahli.

9. Penegakan hukum pidana menahan upah. Beberapa kasus. Pengusaha atau manajemen tentang upah seperti: upah di bawah upah minimum, dan menahan upah sedangkan perkara phk masih diproses di PHI. Padahal UU no 13 tahun 2003 Pasal 184, 185, 186, 187 dan 188 telah menggariskan tindakan itu adalah tindak pidana. Menjadi pertanyaan mengapa belum ada pemidanaan membayar upah di bawah UMP dan terhadap tindakan menahan upah sampai ada putusan yang inkrah.

\section{Penegakan Hukum Jalan Pintas \\ Maksud Jalan Pintas}

Penegakan hukum Indonesia memasuki babak buruk yang saya beri label "jalan pintas" yang cocok sebagai padanannya dalam bahasa Inggris "short cut”. Para subjek hukum Pelanggar dan aparat penegak hukum, tidak mau atau tidak rela mengikuti prosedur peraturan, sehingga ditempuh jalan pintas.

Beragam alasan mengapa menempuh jalan pintas sebagaimana diuraikan berikut ini.

- Alasan pertama, tidak sabar mengikuti prosedur. Seperti semisal antrian, dia aturannya urutan 15 , bila satu antrian 1 menit, berarti menunggu 15 menit, lalu langsung ke depan menemui teman, kenalan, konco, famili atau menyuap. Lewat menemui salah satu yang disebut barusan, dia berhasil mempercepat waktu 15 menit.

- Alasan kedua, tidak menguntungkan. Misalnya seorang aparatur penegak hukum pengadilan, bila mengerjakan dan menyerahkan berkas sesuai prosedur tepat waktu dan tepat cara dengan tanpa bayar tidak menguntungkan. Karena itu agak diperlambat sehingga pihak yang berkepentingan datang, lalu ada kesepakatan pengertian memberi sejumlah uang. Ahirnya berkas selesai dan diserahkan.

- Alasan ketiga, merugikan. Misalnya pengusaha memperhitungkan kalau ada Serikat Buruh di perusahaannya, akan terganggu kebiasaan sesuka hati mengelola perusahaan, dan menikmati sendiri hasil berbisnis sesuka hati. Lalu dengan segala cara ditempuh memphk atau memecat si buruh. Pengusaha bisa pakai polisi, preman, PNS Dinas 
Tenaga Kerja dan Hakim di PHI dan Mahkamah Agung.

- Alasan keempat, kepastian. Berurusan dengan hampir semua instansi tidak ada kepastian hasil dan waktu bila mengikuti prosedur jalan biasa. Maka ditempuhlah jalan toll atau jalan pintas. Kemudian kenyataannya, lebih menguntungkan menempuh jalan pintas daripada megikuti prosedur.

Penjelasan jalan pintas paling cocok dengan contoh pejalan kaki yang tidak mau naik jalan penyeberangan. Kalau naik jalan penyeberangan pasti safe atau selamat, tetapi harus jalan kaki beberapa meter dan naik ke atas, makan waktu dan energi. Lalu ditempuh jalan pintas memotong jalan raya dengan jalan pintas yang berbahaya bahkan bisa nyawa taruhannya, tetapi memang menghemat waktu dan energi.

Siapa pelaku atau subjek jalan pintas? Sesuai dengan data yang dikemukakan di atas, subjek pelanggar hukum dan subjek aparat penegak hukum sama-sama menempuh jalan pintas dengan alasan yang berbeda-beda, serta situasional waktu dan tempat. Dalam kasus yang sama, subjek pelanggar dan subjek aparat penegak hukum sama-sama menempuh jalan pintas dengan alasan yang berbeda-beda atau bisa alasan yang sama dari empat alasan tadi tetapi kepentingan yang berbeda .

Diperoleh juga suatu pemahaman yang menjadi suatu sikap yang berbunyi "hukum untuk dilanggar, bukan untuk dipatuhi”. Hampir semua yang saya ajak diskusi supir-supir mikrolet dan metromini dan juga tukang ojek menyatakan pandangan seperti itu, walaupun ada di antara mereka yang menyatakan itu sambil tertawa atau kelakar. Saya berpendapat keadaan penegakan hukum Indonesia sudah serius untuk mendapat perubahan. Kampanyekan revolusi mental dan wujudkan nawacita.

\section{Jalan Pintas Subjek Pelanggar}

Berbagai alasan menempuh jalan pintas bagi subjek Pelanggar Hukum. Umumnya bagi pelanggar rambu laluntas dan pejalan kaki, alasan pertama tidak sabar membuang waktu beberapa menit. Walaupun tindakan itu melanggar hukum UU no 22 tahun 2009 Tentang Lalu Lintas Angkutan Jalan, dan membahayakan keselamatannya dan keselamatan orang lain. Bagi pengendara sepeda motor melakukan tindakan jalan pintas melawan arus, menghindari memutar arah beberapa ratus meter, membutuhkan waktu beberapa menit. Begitu juga bagi pejalan kaki, bila menaiki jembatan penyeberangan, membutuhkan waktu beberapa menit dan energi, sehingga ditempuh jalan pintas menyeberang di tengah jalan raya. Tindakan jalan pintas tersebut adalah termasuk perbuatan melanggar hukum dan membahayakan dirinya dan diri orang lain. Tetapi memang ada kenyataan lain, yakni tidak semua perlintasan jalan, tersedia jembatan penyeberangan. Sepanjang Jalan Pemuda, Pramuka, Balap Sepeda, dan Perintis Kemerdekaan tidak tersedia jembatan penyeberangan jalan.

Bagi pengusaha modal lemah (UKM) yang dengan jalan pintas menggunakan bahu jalan dan yang menggunakan trotoar adalah menguntungkan. UKM bengkel sepeda motor atau cat mobil yang menggunakan bahu jalan, mereka sadar mengganggu kelancaran lalulintas. Kalau hal ini sebenarnya tidak sulit asal aparat pemerintahan lurah dan camat menertibkannya. UKM yang menggunakan trotoar, seperti yang di Jalan Diponegoro, mungkin jumlahnya ratusan, tetapi setiap hari puluhan ribu pejalan kaki terpaksa menginjakkan kakinya di jalan raya yang kenderaan berkecepatan tinggi, karena semua trotoar telah dipergunakan UKM berdagang. Kenyataan segi lain, memang warga yang berkantor di sekitar membutuhkan mereka. Yang benar adalah, trotoar difungsikan sebagai trotoar, kebutuhan berdagang dan konsumen sekitar dicari jalan keluar seperti model Kuala Lumpur atau model Bangkok.

Subjek Pelanggar Hukum pembuang sampah di sembarang tempat, memilih jalan pintas membuang sampah di sembarang tempat, hanya karena tidak sabar memegang sampahnya sampai ditemukan tempat sampah, ditambah memiliki habitat kotor dan tidak perduli. Selain itu, memang tempat pembuangan sampah jarang ditemukan di sepanjang jalan yang saya teliti. Berbeda dengan Singapur dan Kuala Lumpur, setiap jarak tertentu ada kotak sampah. Karena itu dapat juga dikatakan, Pemerintah DKI Jakarta secara tidak sengaja perencana jalan raya Jakarta menjadi tempat pembuangan sampah.

Subjek Pelanggar Hukum parkir di bahu jalan, memilih jalan pintas parkir di bahu jalan karena menguntungkan. Merekatidakmenyadaritigadampak dari parkir di bahu jalan; memacetkan lalulintas, membahayakan dirinya, dan membahayakan pengguna jalan lainnya.

Subjek pelanggar hukum pembuat kenderaan umum melakukan tindakan jalan pintas sehingga penumpang merasa tidak nyaman terbagi dua kelompok besar, penumpang kriminal (pencopet, perampok dan penodong) serta supir dan kondektur. Supir dan kondektur melakukan tiga jenis jalan pintas; kencang ugal-ugalan, menurunkan penumpang tidak ditempat semestinya, dan memutar arah lalu menurunkan semua penumpang sebelum 
tiba di tujuan. Para supir melakukan lari kencang dan menurunkan penumpang bukan ditempatnya, karena tidak sabar mengejar target. Sedangkan memutar balik arah, karena rugi bila diteruskan. Sementara pelaku kriminal melakukan kejahatan di atas kenderaan umum, karena tidak sabar tidak ada pekerjaan, pemerintah tidak sanggup buka lapangan kerja dan tidak bertanggungjawab menjalankan Pasal 27 (2) UUD 1945.

Subjek Pelanggar Hukum perokok di tempat dilarang merokok, melakukan tindakan jalan pintas, tidak sabar menahan candu rokok hingga ke tempat yang disediakan untuk boleh merokok. Secara psikis merasa dirugikan tidak memenuhi tuntutan badan atas candu rokok.

\section{Jalan Pintas Aparatur Penegak Hukum}

Ada dua kelompok garis organisasi pelaku jalan pintas, yakni eksekutif dan Judikatif. Di Eksekutif ada instansi kepolisian, Kejaksaan, Kementerian Hukum dan HAM dan seluruh intansi sipil yang ada hubungannya dengan penegakan hukum. Dan semua ini secara langsung dan tidak langsung berada di bawah kordinasi Presiden. Sedangkan Judikatif, mulai dari Mahkamah Agung, dan semua peradilan di tingkat banding dan tingkat pertama semuanya berada di bawah kordinasi langsung Ketua Mahkamah Agung.

Subjek Hukum Aparatur Negara Kepolisian dalam hal lalulintas mengambil tindakan jalan pintas tentang penertiban lalulintas bersikap pembiaran di tingkat prajurit, karena alasan rugi tenaga, dan tidak mau capek. Sedangkan di tingkat pimpinan Kapolres, kapolda dan kapolri tidak memiliki komitmen yang kuat untuk menegakkan hukum. Sedangkan tentang pidana perburuhan, pihak penyidik tingkat bawah ragu akan tidak ada kepastian dari pimpinan, sedangkan pimpinan tingkat Kapolda dan Kapolri sepertinya ada komitmen sedapat mungkin tidak mempidanakan pengusaha. Jalan pintas ini perlu peneltiian dan kajian lebih mendalam apakah karena alasan tidak menguntungkan atau dengan alasan memberi keuntungan.

Mengenai peranan Subjek Hukum Aparatur Kejaksaan terhadap pembiaran dan tidak mempidanakanpengusahadalamhubungannyadengan pekerjaan kepolisian membutuhkan penelitian. Sebab penegakan pidana, sangat kuat peranan Kejaksaan melakukan pengawasan pemberkasan perkara.

Demikian juga di jalur Judikatif, perlu juga penelitian lanjutan mengapa penegakan hukum tidak berlangsung sesuai dengan undang-undang.

\section{Hasil Penelitian}

\section{Hasil Penelitian Tahap Pertama Survei}

Berikut inilah jenis atau kategori pelanggaran hukum lalulintas yang acapkali berlangsung di sekitar Pasar Senen.

1. Melawan arus lalulintas.

2. Melewati portal Kreta api saat mulai ditutup.

3. Tidak mempergunakan lampu spion.

4. Motor tidak menggunakan helm.

5. Jualan di bahu jalan.

6. Berdiri dekat rel kereta api.

7. Menerobos lampu merah.

8. Mobil dan motor memutar arah tidak pada tempatnya.

9. Jalan kaki saat lampu hijau.

10. Parkir di bahu jalan.

11. Mobil dan motor menggunakan jalur busway.

12. Melebihi muatan.

13. Meletakkan dagangan di pembatas bus way.

\section{Hasil Penelitian Intensitas Kuantitas Pelanggaran}

Berikut ini intensitas pelanggaran setiap jenis pelanggaran hukum lalu lintas di atas.

\begin{tabular}{|l|l|l|c|l|}
\hline 1 & \multicolumn{4}{|c|}{ Menerobos Lampu Merah } \\
\cline { 2 - 5 } & No & Nama & Motor & Mobil \\
\hline 1 & Gracia & 7 & \\
\hline 2 & Fitriyani & 24 & \\
\hline 3 & Renhart & 27 & \\
\hline 4 & Widia & 49 & \\
\hline 5 & Refael & 13 & 3 \\
\hline 6 & Leonardo & 45 & 15 \\
\hline 7 & Simon & 36 & 4 \\
\hline 8 & Giovani & 30 & \\
\hline 9 & Javier & 18 & \\
\hline 10 & Ivan & 50 & 1 \\
\hline 11 & Amon & 12 & \\
\hline 12 & Julius & 15 & 13 \\
\hline 13 & Yesy & 24 & 12 \\
\hline 14 & Dimas & 46 & 1 \\
\hline 15 & Aureli & 28 & 17 \\
\hline 16 & Naomi & 6 & \\
\hline TOTAL & 430 & 66 \\
\hline
\end{tabular}




\begin{tabular}{|c|c|l|c|c|}
\hline \multirow{1}{*}{} & \multicolumn{4}{|c|}{ Melawan Arus Lalulintas } \\
\cline { 2 - 5 } & No & Nama & Motor & Mobil \\
\hline 1 & Fitriyani & 8 & 13 \\
\hline 2 & Angel & 44 & \\
\hline 3 & Renhart & 34 & \\
\hline 4 & Widia & 35 & \\
\hline 5 & Fisensia & 126 & \\
\hline 6 & Refael & 15 & 3 \\
\hline 7 & Polman & 67 & 17 \\
\hline 8 & Simon & 19 & 1 \\
\hline 9 & Angelia & 38 & \\
\hline 10 & Giovani & 6 & \\
\hline 11 & Javier & 12 & \\
\hline 12 & Gres & 30 & \\
\hline 13 & Ivan & 1 & \\
\hline 14 & Juliyus & 17 & \\
\hline 15 & Yessy & 14 & \\
\hline 16 & Dimas & 1 & \\
\hline 17 & Aurelia & 19 & \\
\hline 18 & Putri & 5 & \\
\hline 19 & Naomi & 17 & \\
\hline 20 & Anggel & 44 & \\
\hline & TOTAL & 552 & 34 \\
\hline
\end{tabular}

\begin{tabular}{|c|c|c|c|c|}
\hline \multirow[t]{16}{*}{3} & \multicolumn{4}{|c|}{$\begin{array}{c}\text { Memutar Arah } \\
\text { Tidak Pada Tempatnya }\end{array}$} \\
\hline & No & Nama & Motor & Mobil \\
\hline & 1 & Widia & 12 & 5 \\
\hline & 2 & Refael & 30 & 2 \\
\hline & 3 & Polman & 14 & \\
\hline & 4 & Leonardo & 50 & 3 \\
\hline & 5 & Shinta & 72 & 10 \\
\hline & 6 & Javier & 37 & 2 \\
\hline & 7 & Deasy & 28 & 19 \\
\hline & 8 & Ivan & 4 & \\
\hline & 9 & Julius & 25 & 14 \\
\hline & 10 & Yesy & 28 & 12 \\
\hline & 11 & Dimas & 68 & 26 \\
\hline & 12 & Amri & 2 & \\
\hline & 13 & Naomi & 7 & \\
\hline & \multicolumn{2}{|c|}{ TOTAL } & 377 & 93 \\
\hline
\end{tabular}

\begin{tabular}{|l|l|l|c|c|c|}
\hline 4 & \multicolumn{5}{|c|}{ Masuk Jalur Busway } \\
\cline { 2 - 6 } & No & Nama & Motor & Mobil & Grobak \\
\hline 1 & Gresia & 5 & & \\
\hline 2 & Fitriyani & 36 & & \\
\hline 3 & Renhart & 18 & & \\
\hline 4 & Giovani & 1 & & \\
\hline 5 & Widia & 8 & 4 & \\
\hline 6 & Refael & 9 & 5 & \\
\hline 7 & Polman & 47 & 7 & \\
\hline 8 & Simon & 6 & 2 & \\
\hline 9 & Shinta & 16 & 15 & 1 \\
\hline 10 & Amon & 27 & & \\
\hline 11 & Yesy & 8 & 20 & 10 \\
\hline 12 & Dimas & 17 & 4 & \\
\hline 13 & Aurelia & 8 & 6 & \\
\hline 14 & Naomi & 3 & & \\
\hline \multicolumn{3}{|c|}{ TOTAL } & 209 & 63 & 11 \\
\hline
\end{tabular}

\begin{tabular}{|l|l|l|c|c|}
\hline 5 & \multicolumn{4}{|c|}{$\begin{array}{c}\text { Berhenti di Marka Jalan/ } \\
\text { Rambu Dilarang Stop }\end{array}$} \\
\cline { 2 - 5 } & No & Nama & Motor & Mobil \\
\hline 1 & Renhart & 22 & \\
\hline 2 & Widia & 26 & \\
\hline 3 & Refael & 90 & 23 \\
\hline 4 & Polman & 70 & 20 \\
\hline 5 & Leonardo & 65 & 10 \\
\hline 6 & Simon & 75 & 10 \\
\hline 7 & Shinta & 1 & \\
\hline 8 & Angelina & 45 & 16 \\
\hline 9 & Giovani & 18 & \\
\hline 10 & Javier & 2 & \\
\hline 11 & Deasy & 38 & 30 \\
\hline 12 & Ivan & 18 & \\
\hline 13 & Juliyus & 28 & 18 \\
\hline 14 & Yessy & 50 & \\
\hline 15 & Dimas & 53 & 14 \\
\hline 16 & Aurelia & 12 & 2 \\
\hline 17 & Naomi & 5 & \\
\hline 18 & Angel & 29 & \\
\hline & TOTAL & 647 & 143 \\
\hline
\end{tabular}




\begin{tabular}{|l|l|l|c|c|}
\hline \multirow{1}{*}{} & \multicolumn{4}{|c|}{ Parkir di Bahu Jalan } \\
\cline { 2 - 5 } & No & Nama & Motor & Mobil \\
\cline { 2 - 5 } & 1 & Gracia & 3 & \\
\hline 2 & Renhart & 9 & \\
\hline 3 & Refael & 48 & 10 \\
\hline 4 & Polman & 17 & \\
\hline 5 & Leonardo & 1 & \\
\hline 6 & Anggelia & 17 & 1 \\
\hline 7 & Deasy & 17 & 10 \\
\hline 8 & Amon & 9 & \\
\hline 9 & Yesy & 14 & \\
\hline 10 & Aurelia & 7 & \\
\hline 11 & Amri & 3 & 3 \\
\hline 12 & Naomi & 7 & \\
\hline & TOTAL & 152 & 24 \\
\hline & & & \\
\hline
\end{tabular}

\begin{tabular}{|l|l|l|c|}
\hline 7 & \multicolumn{3}{|c|}{$\begin{array}{c}\text { Pejalan Kaki Lewat pada Lampu } \\
\text { Hijau dan Tidak Pada Tempatnya }\end{array}$} \\
\cline { 2 - 4 } & No & Nama & Orang \\
\hline 1 & Gracia & 10 \\
\hline 2 & Widia & 24 \\
\hline 3 & Refael & 80 \\
\hline 4 & Simon & 39 \\
\hline 5 & Angelia & 15 \\
\hline 6 & Javier & 7 \\
\hline 7 & Deasy & 21 \\
\hline 8 & Ivan & 17 \\
\hline 9 & Amon & 12 \\
\hline 10 & Dimas & 17 \\
\hline 11 & Naomi & 244 \\
\hline
\end{tabular}

\begin{tabular}{|l|l|l|c|}
\hline \multirow{1}{*}{} & \multicolumn{3}{|c|}{ Motor Tidak Pakai Helm } \\
\cline { 2 - 4 } & No & Nama & Motor \\
\cline { 2 - 4 } & 1 & Fitriyani & 36 \\
\hline \multirow{1}{*}{} & Renhart & 21 \\
\hline \multirow{1}{*}{} & Widia & 14 \\
\hline 4 & Refael & 25 \\
\hline 5 & Polman & 47 \\
\hline 6 & Leonardo & 6 \\
\hline 7 & Simon & 48 \\
\hline 8 & Shinta & 11 \\
\hline 9 & Angelia & 8 \\
\hline 10 & Gres & 15 \\
\hline 11 & Deasy & 42 \\
\hline 12 & Ivan & 1 \\
\hline 13 & Amon & 12 \\
\hline 14 & Juliyus & 18 \\
\hline 15 & Yesy & 14 \\
\hline 16 & Dimas & 12 \\
\hline 17 & Aurelia & 5 \\
\hline & TOTAL & 335 \\
\hline
\end{tabular}

\begin{tabular}{|l|l|l|c|}
\hline 9 & \multicolumn{3}{|c|}{$\begin{array}{c}\text { Meletakkan Dagangan } \\
\text { di Pembatas Busway }\end{array}$} \\
\cline { 2 - 4 } & No & Nama & Motor \\
\cline { 2 - 4 } & 1 & Fitriyani & 11 \\
\hline 2 & Refael & 15 \\
\hline 3 & Angelia & 7 \\
\hline 4 & Amon & 10 \\
\hline 5 & Yesy & 8 \\
\hline & TOTAL & 51 \\
\hline
\end{tabular}

\begin{tabular}{|l|l|l|c|}
\hline 10 & \multicolumn{3}{|c|}{ Jualan di Bahu Jalan } \\
\cline { 2 - 4 } & No & Nama & Motor \\
\cline { 2 - 4 } & 1 & Angel & 24 \\
\cline { 2 - 4 } & 2 & Renhart & 5 \\
\cline { 2 - 4 } & \multicolumn{2}{|c|}{ TOTAL } & 29 \\
\hline
\end{tabular}




\begin{tabular}{|c|c|c|c|}
\hline \multirow{7}{*}{11} & \multicolumn{3}{|c|}{ Melewati Palang KA } \\
\hline & No & Nama & Motor \\
\hline & 1 & Fitriyani & 28 \\
\hline & 2 & Angel & 29 \\
\hline & 3 & Widia & 22 \\
\hline & 4 & Fisensia & 35 \\
\hline & \multicolumn{2}{|r|}{ TOTAL } & 114 \\
\hline
\end{tabular}

\begin{tabular}{|c|c|c|c|c|}
\hline \multirow[t]{5}{*}{12} & \multicolumn{4}{|c|}{ Melebihi Muatan } \\
\hline & No & Nama & Motor & Mobil \\
\hline & 1 & Renhart & 5 & 4 \\
\hline & 2 & Refael & 8 & \\
\hline & \multicolumn{2}{|c|}{ TOTAL } & 13 & 4 \\
\hline
\end{tabular}

\begin{tabular}{|c|c|c|c|}
\hline 13 & & Tidak Me & a Spion \\
\hline & No & Nama & Motor \\
\hline & 1 & Fitriyani & 42 \\
\hline & 2 & Widia & 8 \\
\hline & 3 & Fisensia & 15 \\
\hline & 4 & Dimas & 3 \\
\hline & & TOTAL & 68 \\
\hline
\end{tabular}

\section{Problem Pelanggaran}

1. Pelanggaran di atas sering terjadi padahal ada petugas polisi bahkan didekat pos polisi

2. Ada beberapa pelanggar lalu lintas yang ditilang tetapi marah-marah dan tidak terima ditilang. Widia, Janiver, Gres

3. Ada beberapa pelanggar lalu lintas berplat TNI dan Polisi tetapi tidak ditindak. Refael (1), Shinta, Amon

4. Grobak dagangan yang seenaknya lewat tanpa melihat situasi jalan. Shinta, Deasy (20), Julius 5, Yesy 2, Angel 18+24

5. Bajaj membawa masalah sendiri yang juga seenaknya melanggar lalu lintas bahkan masuk jalur busway.

6. Anak di bawah umur juga sering mengendarai motor yang bisa membahayakan diri sendiri dan orang lain
7. Begitu Palang Kereta Api baru terbuka, langsung yang lewat pejalan kaki dan sepeda motor dari arah melawan arus, kejadian ini menghambat jalannya lalu lintas. Bisa terjadi kenderaan belum lewat, Kereta Api sudah sedang lewat lagi.

Berikut ini adalah rangkuman hasil penelitian tersebut. Jumlah pelanggar lalu lintas dari pukul 06.00 s.d. 18.00 adalah:

1. Yang melakukan menerobos lampu merah selama 32 jam, (16 orang peneliti) adalah $430 \times$ sepeda motor dan $32 \times$ mobil, total $462 \times$. Rata-rata pelaku pelanggaran lalu lintas berupa menerobos lampu merah $14 \mathrm{x}$ tiap jam.

2. Yang melakukan melawan arus lalulintas selama 40 jam, (20 orang) adalah $552 \mathrm{x}$ sepeda motor dan $34 \mathrm{x}$ mobil, total $586 \mathrm{x}$. Rata-rata pelaku pelanggaran melawan arus $15 \mathrm{x}$ tiap jam.

3. Yang melakukan memutar arah tidak di tempatnya selama 26 jam (13 orang) adalah 377 x sepeda motor dan $93 \times$ mobil, total $470 \mathrm{x}$. Rata-rata pelaku pelanggaran memutar arah tidak pada tempatnya $18 \mathrm{x}$ tiap jam.

4. Yang melakukan masuk jalur bus way selama 28 jam, (14 orang) adalah $209 \mathrm{x}$ sepeda motor, $63 \mathrm{x}$ mobil dan gerobak dagang $11 \mathrm{x}$, total 283

x. Rata-rata pelaku pelanggaran masuk jalur bus way $10 \mathrm{x}$ tiap jam.

5. Yang melakukan berhenti di marka yang dilarang Stop selama 36 jam, (18 orang) adalah $647 \mathrm{x}$ sepeda motor, mobil $143 \mathrm{x}$, total $790 \mathrm{x}$. Rata- rata pelaku pelanggaran berhenti di marka yang dilarang stop $22 \mathrm{x}$ tiap jam.

6. Yang melakukan parkir di bahu jalan selama 24

jam, (12 orang) adalah $152 \mathrm{x}$ sepeda motor, $24 \mathrm{x}$ mobil, total 176 x. Rata-rata pelaku parkir di bahu jalan $7 \mathrm{x}$ tiap jam.

7. Pejalan kaki lewat pada saat lampu hijau selama 22 jam (11 orang) adalah 244 x. Tiap jam $11 \mathrm{x}$ tiap jam.

8. Pedagang yang meletakkan dagangannya di pembatas bus way selama 10 jam, (5 orang) adalah 51 x, Rata-rata 5 x tiap jam.

9. Sepeda motor menerobos palang Kreta Api selama 8 jam, (4 orang) adalah sebanyak 144 x. Rata-rata $18 \times$ tiap jam.

10. Sepeda motor tidak memakai helm selama 34 jam, (17 orang) adalah sebanyak 335 x. Rata-rata $10 \mathrm{x}$ tiap jam.

Sepuluh jenis pelanggaran yang dikemukakan di atas, adalah pelanggaran yang berpotensi mem- 
bahayakan diri pelaku, membahayakan diri orang lain, dan menimbulkan kemacetan serta kesemrawutan. Kalau diakumulasi 10 jenis pelanggaran lalu lintas di atas, maka dapat disimpulkan bahwa pelanggaran lalu lintas di lokasi Pasar Senen Jalan Suprapto rel Kereta Api hingga Jalan Kramat Raya, sebanyak 130 $\mathrm{x}$ tiap jam, $2 \mathrm{x}$ tiap menit. Dapat diperkirakan betapa semrawutnya lalu lintas di sekitar Senen, tiap menit ada 2 x pelanggaran.

Ada dua fakta penting yang dapat dikemukakan dari data di atas yakni:

1. Penegakan hukum tidak berjalan. Perlu meniru negara tetangga Singapur dan Malaysia serta umumnya Eropa. Law enforcement yang mereka lakukan adalah bantuan teknologi CCTV. Untuk itu perlu regulasi teknis: a. semua pemilik mobil dan pemilik SIM wajib memiliki no rekening bank. b. Di setiap tempat rawan pelanggaran hukum lalu lintas perlu dipasang CCTV. c. Setiap pelanggaran langsung direkam, dan dendanya langsung dipotong dari rekening.

2 Sarana Lalu lintas umum yang belum memadai Orang sedapat mungkin masih menggunakan sarana lalu lintas milik pribadi, karena sarana angkutan umum yang nyaman (Kereta api dan bus way) belum tersedia cukup untuk semua wilayah. Perlu juga angkutan air sungai dikembangkan. Meneruskan BKT (Banjir Kanal Timur) sampai ke BKB (Banjir Kanal Barat) hingga Pantai Indah Kapuk, terhubung tembus ke laut dan kedalamannya sama dengan laut yang dapat dilalui kapal kecil berpenumpang lebih kurang 100 orang secara teratur. Kemudian diurai lagi dengan sungai-sungai kecil, yang dapat dilalui kapal kecil berpenumpang sekitar 15-20 orang.

\section{Kesimpulan}

1. Menegakkan negara hukum dengan melaksanakan penegakan hukum adalah syarat mutlak mencapai tujuan negara, yang disingkatkan dengan kata welfarestate. Sejak saya berkecimpung sebagai praktisi hukum tahun 1978, saya belum pernah melihat berlangsungnya penegakan hukum yang sungguh-sungguh. Bahkan selama itu saya dapat simpulkan bahwa penegakan hukum Indonesia berjalan tanpa arah dan tanpa pemimpin yang memiliki komitmen yang kuat untuk menegakkan hukum. Bahkan penegakan hukum sering juga dipergunakan menjadi sarana pencapaian kepentingan politik pemimpin. Paling kentara masa pemerintahan Presiden Soeharto dan Soesilo Bambang Yudhoyono.
2. Presiden memiliki kewenangan dan kekuasaan yang kuat untuk menegakkan negara hukum dan melaksanakan penegakan hukum. Kekuasaan penegakan hukum formal Kepala Kepolisian, Jaksa Agung dan Menteri Hukum dan HAM berada di bawah tanggung jawab dan kontrol presiden, ditambah penegakan hukum lewat kekuasaan administrasi sipil eksekutif seluruh Menteri, Gubernur dan Bupati/Walikota. Wajar bila rakyat memberi harapan besar kepada setiap presiden baru, mulai dari Gus Dur, Megawati, Susilo Bambang Yudhoyono dan sekarang Joko Widodo.

3. Tidak ada perubahan atau perbedaan secara signifikan penegakan hukum antara Juni 2013Oktober 2014 dengan Oktober 2014-Juli 2017. Yang terjadi adalah keberlanjutan secara siginifikan Juni 2013-Oktober 2014 ke Oktober 2014-Juli 2015 dengan dua objek penelitian yakni penegakan hukum kehidupan seharihari lalu lintas dan penegakan hukum perburuhan. Berarti berdaulat bagian trisakti dan penegakan hukum nawacita serta revolusi mental janji politik kampanye pasangan calon Presiden- Wakil Presiden Jokowi-JK tidak dikerjakan secara sungguh-sungguh sehingga tidak memberi perubahan signifikan dalam penegakan hukum objek penelitian ini.

4. Sebenarnya secara fakta ada beberapa kepala pemerintahan yang memiliki komitmen kuat menegakkan negara hukum dan melaksanakan penegakan hukum, dan nama mereka menjadi teladan di dunia internasional. Di antara mereka adalah Lee Kwan Yew Singapur, Kim Dae Yung Korea Selatan, Lech Walesa Polandia, Lulla da Silva Brazilia, dan Nelson Mandela Afrika Selatan. Pertanyaan yang lahir dari penantian pengharapan, kapan Indonesiamemilikipemimpin yang seperti salah satu dari mereka. Sudah terlalu lama rakyat negara yang sangat kaya alamnya ini menderita dipimpin oleh seorang pemimpin yang lemah komitmennya menegakkan negara hukum dan melaksanakan penegakan hukum.

\section{Saran}

Saat makalah ini rampung usia pemerintahan Jokowi-JK genap 3 (tiga) tahun. Kenyataan penyelenggaraan pemerintahan tidak sesuai dengan janji politik waktu kampanye: welfarestate, Trisakti, Nawacita, dan kabinet ramping, bersih, professional dan non-transaksional. Namun demikian popularitas 
Joko Widodo semakin meningkat, $70 \%$ puas dan percaya. Tetapi mulai timbul kekecewaan di kalangan masyarakat yangmemahami hukumdan ketatanegaraan yang diperlihatkan dalam diskusi-diskusi terbuka dan tertutup. Masih ada waktu dua tahun lagi. Diharapkan Presiden Joko Widodo menepati janji politiknya minimal komitmen menegakkan hukum. Hukumperlu ditegakkan, lewat penegakan hukum korupsi yang merajalela dapat diberantas. 


\section{Daftar Pustaka}

Abintoro Prakoso, Prof. Dr., Drs., SH., MS, Hukum, Filsafat Logika dan Argumentasi Hukum, LaksBang Justitia, Surabaya, 2015.

Bambang Waluyo, Penegakan Hukum di Indonesia, Sinar Grafika, cetakan kedua 2017, Jakarta.

Fajlurrahman Jurdi, Teori Negara Hukum, Setara Press, Malang, 2016.

Efran Helmi Juni, Filsafat Hukum, Tim Pustaka Setia, Bandung, 2012.

FokusMedia, UUD'45 dan Amandemennya.

Jimly Asshidiqqie, Penegakan Hukum, www.docu- desk.com Selasa 30 Juni 2015.

Macmillan. Dictionary, Macmillan Publishing Co,,Inc, Newyork and Collier Macmillian publisher.

Muchtar Pakpahan, DPR Semasa Orde Baru, Sinar Harapan, Jakarta, 1993.

Muchtar Pakpahan, Potret Negara Indonesia, cetakan III, PT BIS, 2011.

Otje Salman., Prof. Dr., SH, Filsafat Hukum (Perkembangan Dinamika Masalah), Refika Aditama, Bandung, 2012.

Philipus M. Hadjon., Prof., Dr., SH, Ide Negara Hukum Dalam Sistem Ketatanegaraan Indonesia, dalam buku Kedaulatan Rakyat, Hak Azasi Manusia dan Negara Hukum, Sebuah Kumpulan Esai, Editor Bagir Manan, Penerbit Gaya Media Pratama, 1996.

Sadjijono, Prof.,Dr.,SH.,M.Hum, Hukum Antara Sollen dan Sein (Dalam perspektif Praktek Hukum di Indonesia).

Satjipto Rahardjo., Prof., Dr., SH, Penegakan Hukum, Suatu Tinjauan Sosiologis, Genta Publishing, cetakan II 2011.

Soekarno, Pleidoi Indonesia Menggugat.

Undang-Undang RI Nomor 2 tahun 2004 tentang Penyelesaian Perselisihan Hubungan Industrial. Undang-Undang RI Nomor 13 tahun 2003 tentang Ketenagakerjaan.

Undang-Undang RI Nomor 21 tahun 2000 tentang Serikat Pekerja/Serikat Buruh Undang-undang RI Nomor 22 tahun 2009 tentang Lalulintas Jalan 